\title{
The Human as Encounter: Karl Barth's Theological Anthropology and a Barthian Vision of the Common Good
}

\author{
Benjamin Durheim ${ }^{1}$ \\ Boston College Department of Theology
}

Karl Barth was one of the most influential theologians of the $20^{\text {th }}$ century. Although he was prolific on many topics in theology, he is not often thought of as articulating a vision of the common good. This project attempts to glean from Barth's theology the building blocks for such a vision, and takes some initial steps toward actually building it, given the material Barth provides. The paper begins by exploring the way Barth constructs his theological anthropology, arguing that its central theme is what he calls "encounter," characterized by four main elements: seeing eye-to-eye, exchanging speech and hearing, giving and receiving assistance, and doing all these things in a spirit of gladness. The paper then progresses to build on his theological anthropology a structure for envisioning the common good. Claiming that Barth's concept of encounter provides the nexus between his theological anthropology, social ethics, and what I claim would be a Barthian vision of the common good, the paper finishes by teasing out two main elements of such a vision: societal interactions as the Barthian encounter, and the relationship of the Church and society as a similar encounter.

Benjamin Durheim is a Ph.D. student in the Theology Department of the Graduate School of Arts and Sciences at Boston College. His focus is in systematic theology, with particular interests in liturgical/sacramental theology, as well as the theologies of Karl Barth and Søren Kierkegaard. 


\section{Introduction}

Karl Barth was one of the most influential theologians of the $20^{\text {th }}$ century. Although he was prolific on many topics in theology, he is not often thought of as articulating a vision of the common good. He certainly wrote a number of works that carry implications for Christian ethics and engagement in politics, but these works often stop short of constructing a positive and systematic vision for human society. Can Barth's work provide a vision of the common good, and if so, what would it look like? This project attempts to glean from Barth's theology the building blocks for such a vision, and takes some initial steps toward constructing it, given the material Barth provides.

The discussion is divided into two sections: first, it explores the way in which Barth constructs his theological anthropology. Since articulating a vision of the common good is the goal, an apt starting point is how Barth sees the human person in relation to God and other humans. The discussion argues that the central theme in Barth's theological anthropology is what he calls "encounter," characterized by four main elements: seeing eye-to-eye, exchanging speech and hearing, giving and receiving assistance, and doing all these things in a spirit of gladness. The second section of the project then briefly narrates Barth's development from his work The Epistle to the Romans into the Church Dogmatics, and progresses to build on his theological anthropology a structure for envisioning the common good. Claiming that Barth's concept of encounter provides the nexus between his theological anthropology, social ethics, and what I claim would be a Barthian vision of the common good, the discussion finishes by teasing out two main elements of such a vision: societal interactions as the Barthian encounter, and the relationship of the Church and society as a similar encounter. 


\section{Karl Barth's Theological Anthropology}

In order to take an accurate, albeit brief, snapshot of Barth's theological anthropology, this section explores three main avenues in his thinking about humanity. First, the section explains the main points of Barth's Trinitarian theology, and the ways in which it can —and cannot - inform theological anthropology. After establishing the relationship in Barth's thought of the Trinity to humankind, the section goes on to articulate the interplay of Christology and theological anthropology, especially as it informs Barth's concept of humanity as covenantpartner with God. Third and finally, the section ends with Barth's account of human sin, and how that and the relations to Christ and the Trinity constitute humanity as being-in-encounter.

While an in-depth study of Barth's theology of the Trinity runs beyond the scope of this discussion, a brief look at its influence on Barth's theology of personhood is certainly warranted. For Barth, it is through Jesus Christ that we are able to know anything at all about God. ${ }^{2}$ This is a fundamental tenet in Barth's theology: the entirety of theology must be rooted in that which has been revealed. In Barth's words, "Revelation in fact does not differ from the person of Jesus Christ nor from the reconciliation accomplished in Him. To say revelation is to say 'The Word became flesh." ${ }^{, 3}$ With reference to Trinitarian theology, this means that, on the one hand, all that can be known about God-in-Godself can only be appropriated by the revelation of Jesus Christ, and on the other, that revelation in Jesus Christ grants us a "share in the truth" of the wholeness of the Triune God. ${ }^{4}$

\footnotetext{
${ }^{2}$ Gary W. Deddo, Karl Barth's Theology of Relations: Trinitarian, Christological, and Human: Towards an Ethic of the Family (New York: Peter Lang, 1999), 19.

${ }^{3}$ Karl Barth, Church Dogmatics I/1, $2^{\text {nd }}$ ed., trans. G.W. Bromiley, eds. G.W. Bromiley and T.F. Torrance (Peabody, MA: Hendrickson, 2010), 119.

${ }^{4}$ Karl Barth, Church Dogmatics II/1, $2^{\text {nd }}$ ed., trans. T.H.L. Parker, et al., eds. G.W. Bromiley and T.F. Torrance

(Peabody, MA: Hendrickson, 2010), 51.
} 
This last point is the one upon which Barth bases his theology of the Trinity. For him, in the revelation provided in Christ, we humans can glimpse the actual life of God as Trinity. There is no hidden reality of God contrary to Trinitarian life. In his words, "God is who He is, the Father, Son and Holy Spirit ... and He is known in this entirety or He is known not at all. There is no existence of God behind or beyond this entirety of His being." ${ }^{5}$ For Barth then, the Trinity is a reality that we know only through Jesus Christ, and Christ reveals a "share" of the wholeness of the Trinity. In this way Barth can (in his view) root himself solidly in revelation rather than philosophy or natural theology, and still arrive at the Triune God.

The Triune God revealed by Christ is, for Barth, a "Triunity," by which he means to conflate the concepts of "unity in trinity," and "trinity in unity.", These two concepts refer to the two major points of Trinitarian theology that, if taken too far, result either in tritheism (the danger of trinity in unity) or modalism (unity in trinity). What Barth tries to accomplish with the concept of Triunity is both to walk the tightrope between tritheism and modalism, and to steer away from overusing the term "person" in talking about God; he views it as too easily connoting human personhood. ${ }^{7}$ Barth prefers to speak of triune "relations" rather than persons. For him, the terms "Father," "Son," and "Holy Spirit" refer more correctly to relations within God than to discrete entities that can be separated from each other. Even in this use of names and relations within the Triunity, Barth is careful to stress the inadequacy of such terms, but his point is that the Triunity exists as a life of relationships. ${ }^{8}$ Whatever else springs from Barth's Trinitarian

\footnotetext{
${ }^{5}$ Ibid. For this discussion, I leave Barth's exclusively male language as-is, and proceed as if he actually means by the generic term "men," "humanity." However, determining whether this is actually the case, and whether and to what degree his exclusive language limits his theology's applicability and usefulness, would be a question worth exploring. That being said, such an exploration reaches beyond the limits of the current discussion.

${ }^{6}$ Barth, Dogmatics I/1, 368-369.

${ }^{7}$ Ibid., 358-364. Alan J. Torrance has critiqued Barth's hesitancy to take on the term "person" more wholeheartedly. Cf. Alan J. Torrance, Persons in Communion: An Essay on Trinitarian Description and Human Participation with Special Reference to Volume One of Karl Barth's Church Dogmatics (Edinburgh: T\&T Clark, 1996), 225-262. ${ }^{8}$ Deddo, 24-25.
} 
theology, this is the most important point for the purposes of this discussion: For Barth, the reality of God (and as we will see, the reality of humanity) is essentially characterized by relationship. In his words, “God's essence is indeed one, and even the different relations of origin do not entail separations ... for where there is difference [in God] there is also fellowship."9

The question now becomes, how can Barth move from Triune relations to human relationships? It should first be noted that he does in fact do so- the Triune life in his conception is not irrelevant to humanity, nor is it based on extrapolating human concepts to some "perfect" limit. However, there is a particular way in which Barth relates the Triunity to humanity. Barth's objection to any concept of an analogia entis is well known, so it would be insufficient to claim simply that for Barth, just as the Triunity lives, so ought humanity to live. ${ }^{10}$ Rather, Barth proposes what he calls an analogia relationis, that is, an analogy of relations. ${ }^{11}$ In Barth's thought, the analogia relationis is not an analogy between intra-Triune relations and inter-human relations, but rather is one between the intra-Triune relations and the relationship between God and humanity. ${ }^{12}$ This is partly an implication of Barth's insistence on the radical reliance on revelation in Jesus Christ. In order to know anything at all about God, or anything about how we humans may relate to God, we rely on the analogy between the way God relates to Godself on the one hand, and the way God in Christ relates to humanity on the other.

\footnotetext{
${ }^{9}$ Barth, Dogmatics I/1, 370 .

${ }^{10}$ One ought to note, as Daniel J. Price does, that, "a consensus is forming that Barth misinterpreted, to some degree at least, Aquinas' usage of analogia entis," and that such a consensus need not necessarily undermine Barth's alternative (Daniel J. Price, Karl Barth's Anthropology in Light of Modern Thought (Grand Rapids, MI: William B. Eerdmanns, 2002), 132-133.). This discussion proceeds with the presumption that Price is correct in continuing to value Barth's contribution.

${ }^{11}$ Karl Barth, Church Dogmatics III/2, $2^{\text {nd }}$ ed., trans. H. Knight, et al., eds. G.W. Bromiley and T.F. Torrance (Peabody, MA: Hendrickson, 2010), 220.

12 Ibid.
} 
The analogia relationis provides Barth with an avenue in moving from speaking of the God-God relations to speak about the human-God relationship, and finally human-human relationships. However, because the analogia relationis refers to the analogy between Triune relations and the human-God relation, the necessary intermediate step between God-God and human-human relations is, for Barth, Christology—specifically Jesus Christ as the "man for other men."13 While it is true that for Barth, "Christology is not anthropology,"14 such a statement is meant to stress that there are both similarities and differences between the man Jesus Christ, and humanity in general. While the similarities are what ultimately interest this discussion, the differences nonetheless require a brief description, in order at least to provide a cautionary clarification.

As Stuart McLean explains, there are two basic differences between the man Jesus Christ and the rest of humanity in Barth's thought: "first, He is for man from the beginning; and second, He acts on behalf of man as his deliverer."15 The first difference has to do with Christ's orientation toward the good of humankind in its original and unique form. Christ is unstained by human sin, so for his entire existence he shows forth the imago Dei as an entity standing for the good of its fellows. ${ }^{16}$ In this sense Jesus Christ is the man-for-others; he reflects the Triune being-for-others as a human for other humans. The second difference is that of the unique role of Jesus Christ in the economy of salvation. It can hardly be overemphasized that for Barth, there is one savior, one redeemer: the man Jesus. Other humans do not and cannot participate in this role,

\footnotetext{
${ }^{13}$ Barth, Dogmatics III/2, 212.

${ }^{14}$ Ibid., 222.

${ }^{15}$ Stuart D. McLean, Humanity in the Thought of Karl Barth (Edinburgh: T\&T Clark, 1981), 38.

${ }^{16}$ Barth, Dogmatics III/2, 219.
} 
except by inheriting the fruits of Christ's work. The redemptive role of Christ is unique; he saves humankind, and in that capacity, he is alone and inimitable. ${ }^{17}$

These two differences provide the springboard for speaking of the similarities between Jesus Christ and the rest of humanity. First, Christ as redeemer has restored to humankind the destiny of being a "covenant partner" with God. To understand this, one must realize that "real man," for Barth, is a person in relationship with God—a relationship unobstructed by $\sin .{ }^{18}$ This marks the human nature embodied in Christ as markedly distinct from that embodied by the rest of humankind. ${ }^{19}$ Humans bear the stain of sin, and so relating to God by their own power is impossible. However, while sin corrupts the destiny of humanity such that it is rendered incapable of relating to God, Jesus restores that destiny such that humans will be covenant partners with God as Christ always ever is. ${ }^{20}$ Because of the endurance of sin, humankind is not fully capable of its destiny yet, but ultimately it will be.

This first similarity — the restoration of humankind's nature and destiny as "true man"allows the second to spring forth: the similarity of being-with one's fellows. The restoration in Christ of some kind of incomplete relationship between God and humanity makes possible humankind as being persons with one another, and consequently also for one another (in a moment we shall explore how for Barth the former leads to the latter). For Barth, to conceive of a solitary human being is a simple impossibility. As he states, "If we see man in and for himself, and therefore without his fellows, we do not see him at all. If we see him in opposition or even neutrality towards his fellows, we do not see him at all." ${ }^{21}$ For Barth, it is non-human to strive to be on one's own, apart from others. Experiencing oneself as an "I" in relation to the "thou"

\footnotetext{
${ }^{17}$ Ibid., 222-224.

${ }^{18}$ Price, 129.

${ }^{19}$ Barth, Church Dogmatics III/2, 51.

${ }^{20}$ Ibid., 225.

${ }^{21}$ Ibid., 226-27.
} 
constitutes the very human condition. ${ }^{22}$ To be human in Barth's vision, that is, to appropriate in whatever incomplete way the "true man," is to be in relation with other humans.

This insight provides Barth with the foundation for the specifically anthropological side of his theological anthropology. To say "I am human," for Barth, is to say "I am-in-encounter.,"23 Barth sets up what he calls "encounter" as the basic predicate of human existence. For Barth, encounter is the next conceptual step beyond maintaining that humans, simply by being humans, relate to one another; encounter is the way humans relate to one another as true humanity. ${ }^{24}$ According to Barth, encounter is constituted by four essential elements: (1) looking each other in the eye, (2) mutual speech and hearing, (3) mutual assistance, and (4) doing so with gladness. ${ }^{25}$

The first essential element of encounter, that of humans looking each other in the eye, connotes for Barth the necessary equality in which true human encounter must take place. For Barth, "To see the other ... means directly to let oneself be seen by him. If I do not do this, I do not see him." ${ }^{26}$ There is an equal ground, an element of openness, which characterizes human encounter; one person sees the other, and in that act must be seen by the other. To see in secret is not possible in this vision, because true sight is predicated only by also being seen. In other words, human encounter is always embedded in the human conditions of temporality—no one can look in from the outside and gain a privileged view of reality. Our very humanity precludes such a possibility; the only way humans can truly encounter one another is dialogically (openly) as equals. $^{27}$

\footnotetext{
${ }^{22}$ Ibid., 244-247. Barth is dependent in large part for this "I-thou" formulation on the thought of Martin Buber. See for example Martin Buber, I and Thou, ed./trans. Walter Kaufmann (New York: Touchstone, 1970), 51-183.

${ }^{23}$ Ibid., 247.

${ }^{24}$ It bears repeating that for Barth, true humanity is only possible by participation in the redemption of Jesus Christ. Humanity as encounter depends upon saying with Christ, "I am as thou art." Apart from Christ, encounter in this sense is impossible. (Price, 143-144).

${ }^{25}$ Barth, Dogmatics III/2, 250-274.

${ }^{26}$ Ibid., 250.

${ }^{27}$ Ibid., 250-252.
} 
The second element of encounter, that of humans' shared speech and hearing, is not so much qualitatively different from the first as it is quantitative. Though humans do see and are seen by one another, the depth of their sharing — the depth of the encounter — must be more than simply regarding one another at a distance. In true human encounter there is a component of selfcommunication that is necessary, as well as a component of reception of the other's communication. This is how humans come to know one another; they share speech and hearing such that they may make known to each other their identities. Barth is insistent that such activity is both active and receptive: "The I has also to receive the expression of the other. A word heard by me is the active self-declaration of the Thou to me." ${ }^{28}$ As humans see each other, so they also express themselves to each other.

The third element of encounter is the point at which Barth moves from humanity as being-with toward humanity as also being-for. Human existence as being-in-encounter touches on the "true man" exemplified by Jesus Christ, and as such is only ever truly encounter to the degree that it is in accord with the true human. In Barth's words, "Measured by the man Jesus ... if our action is human, this means that it is an action in which we give and receive assistance. An action in which assistance is either withheld or rejected is inhuman." 29 Neutrality, to say nothing of animosity, is not possible in true human encounter. The very nature of humanity, since it is to Christ that we look in order to see that true nature, is revealed as a nature of helping one another. It is not simply that humankind lives in relationships; humankind, in order to be truly human, must live in relationships of assistance. ${ }^{30}$

\footnotetext{
${ }^{28}$ Ibid., 255.

${ }^{29}$ Ibid., 262.

${ }^{30}$ Ibid.
} 
The fourth and final element of encounter is the spirit in which the first three ought to occur if they are to truly embody human nature as Christ revealed it: the spirit of gladness. ${ }^{31}$ For Barth, this is not something added on to the first three elements; gladness is the orientation that makes the first three possible at all. ${ }^{32}$ To understand this, one must note that for Barth, the alternative to gladness would not be reluctance or resentment, but would rather be neutrality, i.e. the stance from which it would be possible to choose gladness or its opposite. ${ }^{33}$ In Barth's vision, either encounter must take place in gladness, or it must take place in neutrality, so that humans could choose between gladness and something else. However, if encounter were to take place in neutrality, encounter itself would be severed from the innermost essence of humanity. ${ }^{34}$ It would be "an accidental fact of human existence." 35 If humans could choose whether to encounter each other gladly or not, true encounter would be subsequent and secondary to existence, and this is impossible for Barth. ${ }^{36}$ As Christ exhibits gladness in encounter, so must humankind, else it is not true encounter, and so not true humanity.

\section{Karl Barth on Politics and the Church}

After briefly examining Barth's theological anthropology, this discussion now turns to how Barth sees such an anthropology playing out in the temporal realities of politics and the Church. First, this section briefly explores Barth's political ethics, especially as they developed between his Epistle to the Romans and the Church Dogmatics. Then, this section moves to an

\footnotetext{
${ }^{31}$ Ibid., 265.

32 Ibid.

${ }^{33}$ Ibid., 266.

${ }^{34}$ Ibid.

${ }^{35}$ Ibid., 267. Emphasis removed. The question might be asked here of how Barth conceives of human persons who are outside the Church, since his being-in-encounter is tied very closely to the true man, Jesus Christ. Such a question would be worthy of exploration, but runs beyond the scope of this discussion.

${ }^{36}$ Ibid. It is certainly true that many people live as if they can choose between encounter in gladness and encounter in some other spirit. However, this for Barth would be something less than true encounter; it would be a selfdeception. True human encounter is for Barth always characterized by gladness.
} 
investigation of how Barth's thought may lend itself to a vision of the common good, particularly in how he sees the specific role of the Church in society.

Barth's thought about theology and politics is often described in terms of development, beginning roughly with his work The Epistle to the Romans, and undergoing clarification and nuance up to and throughout his Church Dogmatics. ${ }^{37}$ The Epistle to the Romans is a dialectical work, reacting to what Barth thought of as the "double insanity" that undergirded much of the German theology that was used to fuel World War I. ${ }^{38}$ On the one hand, Adolf von Harnack (advising Kaiser Willhelm II) had largely identified German nationalistic concerns with the call of God, and on the other the German Social Democrats, in their support for the war, could in no way provide a viable alternative political intimation of Christianity. ${ }^{39}$

In the face of this conflation of Christianity and society, Barth began to develop an ethic of the Word of God, that is, to establish theological bounds within which ethics must operate, based on the absolute freedom of God as a subject. ${ }^{40}$ For the Barth of Romans $I I,{ }^{41}$ the primary locus of human action, and so the primary locus of ethics, is that of the human being in direct relation to God. In Barth's words, "There is no such thing as life in itself: there is only life in relation to God .... We live only-unto the Lord." "42 This position led to two main aspects of ethics in Barth's early thought, both related to the concept of ethics as witness. First, it allowed Barth to emphasize crisis as the situation in which humans experience an awakening to God,

\footnotetext{
${ }^{37}$ Randi Rashkover, Revelation and Theopolitics: Barth, Rosenzweig and the Politics of Praise (London: T\&T Clark International, 2005), 122. For an in-depth study of the development of Barth's thought, see Bruce L. McCormack, Karl Barth's Critically Realistic Dialectical Theology (Oxford: Clarendon, 1995).

${ }^{38}$ Frank Jehle, Ever Against the Stream: The Politics of Karl Barth, 1906-1968, trans. Richard and Martha Burnett (Grand Rapids, MI: William B. Eerdmans, 2002), 36-37.

${ }^{39}$ Ibid.

${ }^{40}$ Robin W. Lovin, Christian Faith and Public Choices: The Social Ethics of Barth, Brunner, and Bonhoeffer (Philadelphia: Fortress, 1984), 22-23.

${ }^{41}$ The first edition of the Epistle to the Romans was written in 1919. Barth then revised it significantly and published a second edition, often referred to as Romans II, in 1922 (Jehle, 37). It is this second edition that became most widely known and influential.

${ }^{42}$ Karl Barth, The Epistle to the Romans, $6^{\text {th }}$ ed., trans. Edwyn C. Hoskyns (New York: Oxford University Press, 1968), 512. Emphasis in original.
} 
specifically as God the judge. ${ }^{43}$ For Barth, the experience of historical crises, predicated by human sin, can throw into sharp relief the contradiction between our sinful experience and the life to which God calls humans. This experience of historical crises then gives way to the experience of the personal krisis, that is, the awareness of one's guilt before the judgment of God. ${ }^{44}$ On the world scale, this krisis is located in the cross, the place where the depths of human sin and guilt touch the very Word in Jesus Christ. ${ }^{45}$ On its own, the Christian witness to the cross does little more than awaken humanity to its guilt before the Lord. What Barth develops then, in order to complete an ethics of witness, is the second aspect: that of witnessing to the resurrection.

Randi Rashkover explains that for Barth in Romans II, guilt discovered in krisis gives way by the resurrection to a new relationship with God: "Subsequent to the Krisis of the cross, the resurrection permits the defeated individual to re-encounter God, now as forgiving and loving." 46 This forgiving and loving God moves the Christian, by Grace, to faith and subsequent obedience (both intimations of Christian witness), ${ }^{47}$ and that movement is where Barth locates ethics. To the extent that the Barth of Romans II can be said to have a positive theological ethics, this would be it: Grace moves the human out of sin and into faith, with obedience to the point that "he that has received Grace neither knows nor wills sin." "48 To live as a Christian is to bear witness to the cross and resurrection by appropriating the gift of God's Grace.

One might suggest at this point that such an ethics of witness does not account for the particularities of Christian life in society — where are the ethical rules, norms, or guidelines? In a sense, as Robin W. Lovin points out, that is exactly the point of Romans II; there are no ethical

\footnotetext{
${ }^{43}$ Lovin, 22.

${ }^{44}$ Rashkover, 125.

${ }^{45}$ Rashkover, 124-125.

${ }^{46}$ Ibid., 126.

${ }^{47}$ Ibid., 126-127.

${ }^{48}$ Barth, Romans II, 191.
} 
rules or norms of which we can be certain, because to confess that there are would be to put limits on the infinite freedom of God. ${ }^{49}$ Instead of ethical norms, Barth seems to advocate for discernment of the divine command in each discrete human situation. For Barth, it is repentance, not good works, which is the primary ethical action, so all other ethical actions are secondary. ${ }^{50}$ As such, ethical actions other than repentance must be ordered by God's Grace, which rushes into the Christian life through the primary action of repentance. Such a conception precludes objective judgment of human actions. It is God's Grace, appropriated in repentance, that must guide the ethical life, and so ultimately humans are unable to assess the righteousness of others' actions with any certainty - human life is ambiguous. ${ }^{51}$ Barth's ethical system in this regard is not empty; it is just personal and intentionally unsystematic.

It is precisely on this point however, that this discussion can now turn to the question of the common good. If ethics in Barth is exhausted by personal human responses to Grace in repentance, how can Barth conceive in any useful way of how humans ought to live together? In short, is there any concept of the common good that can be taken from Barth?

While such a question is not unfounded, something of an answer can be found in Barth's development from Romans II into the Church Dogmatics. First, Barth in the Dogmatics is able to take the time to construct a coherent theological anthropology out of which his ethics can grow. What in Romans II was essentially an anthropology of krisis and experience of Jesus's resurrection, has in the Dogmatics become a Christology of analogia relationis and an anthropology of being-in-encounter. It is no mistake that Barth in Romans II can claim that, since refraining from judgment is the only possibility with regard to human actions, “.... even this

\footnotetext{
${ }^{49}$ Lovin, 28-30.

${ }^{50}$ Barth, Romans II, 436. One might see here a tentative link between being-in-encounter and Barth's idea of repentance. However, developing such a link would be premature in the Barth of Romans II. As such, this discussion moves on to Barth through the Dogmatics before it returns to humans as being-in-encounter. 51 Ibid.
} 
possibility is no possibility, no recipe; it provides no standard of conduct, ${ }^{, 52}$ and then later in the Dogmatics he can claim, “....we have not only to consider a vertical dimension,... We have thus to consider the horizontal as well, and therefore the constancy and continuity both of the divine command and human action."53

In the Dogmatics, Barth is able to lay the foundations for a more robust theological anthropology. What characterizes true human encounter ought to characterize human life. In a sense, the elements of encounter become for Barth the general ethical norms that his earlier thought lacked. This is of course not to claim that in the Dogmatics Barth has constructed a wholly satisfactory ethical system, but it is to maintain that Barth's mature thought does lend itself to practical human living, including giving flesh to some concept of the common good. A Barthian vision of the common good would necessarily be dependent upon the practice of true human encounter-characterized by the four elements of looking each other in the eye, mutual speech and hearing, mutual assistance, and doing so with gladness - cast most explicitly in terms of the love of neighbor.

The love of neighbor is the second part of answering the question of the common good in Barth. "Love of neighbor" does not surface extensively when Barth forms his theological anthropology, but it is for him the concrete form of true human encounter. Recall that for Barth, true human encounter depends on the "true man" Jesus Christ, and it is humanity’s approximation of that true humanity that makes an approximation of true encounter, that is, an approximation of love of neighbor, possible. The command of God, felt as the push of Grace in the state of repentance, "....inevitably calls [the human] to obedience and sanctifies him to the

\footnotetext{
${ }^{52}$ Barth, Romans II, 515.

${ }^{53}$ Karl Barth, Church Dogmatics III/4, $2^{\text {nd }}$ ed., trans. A.T. Mackay, et al., eds. G.W. Bromiley and T.F. Torrance (Peabody, MA: Hendrickson, 2010), 17.
} 
extent that he stands in [relationships to near and distant neighbors]." ${ }^{, 54}$ All this is to say that love of neighbor, as the embodiment of true human encounter, constitutes the doorway into a Barthian vision of the common good.

Two main issues present themselves at the outset of turning explicitly to Barth on the common good. First, there is the issue of translating an ethic of witness and encounter meant for the human person living with other human persons on the one hand, into one that is applicable to human communities living with other human communities on the other. Barth's true human encounter is primarily something that occurs between human persons, guided by the true man Jesus Christ. How can this encounter, even when it manifests itself truly as love of neighbor, be cast in terms of communities, societies, and nations (and so be applicable to a vision of the common good)?

Barth hints at answering this question when he speaks of near and distant neighbors. For Barth, the divine command (which directs human encounter as love of neighbor) touches the human person distinctly as one embedded in a particular context, which de facto places that person in a network of particular relationships. In his words, "Since God addresses [the human] as the man who exists in these particular relationships to the men of his own and other races, they acquire for him the character of an allotted framework in which he has to express his own distinctive obedience. ${ }^{, 55}$ For Barth, the particular relationships that make up a human's contextual framework take three main forms (which will be more fully explained in a moment): shared language, shared geographical location, and a common view of history. ${ }^{56}$ It is not clear that Barth would object to speaking of relationships like family, co-workers, friendships, etc., as making up one's context; rather, the three main forms he mentions serve as a basis out of which

\footnotetext{
${ }^{54}$ Ibid., 287.

${ }^{55}$ Ibid., 288.

${ }^{56}$ Ibid., 289, 291, 294.
} 
to work. His point is that encounter is always embodied in a particular time and place. God's command to love one's neighbor then, is not isolated from the communal constitution of human reality; it rather characterizes the particular human's engagement of that reality. In speaking of near and distant neighbors, Barth attempts to give concrete expression to such a communal vision of human societies.

For Barth, the three ways of speaking about context constitute the main thrust of his discussion of near and distant neighbors. Nearness and distance from one's neighbors are often measured by the issues of common language, common geographical area, and common historical experience, and these are all rooted in particular experiences: A human person always finds himor herself in encounter with others who have the same (or different) language, live in the same (or different) area, and regard history from a similar (or different) viewpoint. In these encounters, the command of God to love one's neighbor becomes the question of how to: see eye to eye with one's neighbor, talk to and hear from one's neighbor, give assistance to and receive it back from one's neighbor, and to do all this in a spirit of gladness. It need not be a massive leap from this as the encounter of the single human with other humans, to the encounters of communities of humans with other human communities. The same sorts of questions would prevail: how can we see eye to eye? How can we talk to the others, and understand them in return? How can we give assistance to the others, and receive from them the gifts they offer? And finally, how can we do these things in gladness? The common good, through a Barthian lens, is in the first place a vision of personal and - this is where creativity of vision will be needed-communal encounter.

Such a vision of personal and communal encounter carries with it all the implications that a specifically personal vision of encounter does. Repentance still remains the primary ethical action, but in communal terms this would take the form of repentance for social structures of $\sin$. 
Love of neighbor still remains the overarching command of God, but in communal terms the task would be to love neighboring peoples, cultures, and even religions. ${ }^{57}$ True human encounter, based in the true man Jesus Christ, still remains the background structure to the concrete form of loving one's neighbor, but in communal terms this would connote true human encounters between differing political groups, economic strata, and even nation-states. The implications of Barth's theological anthropology of encounter for the common good are implicit in his theology; they just require a creative translation into clarity. In this light, this discussion now turns briefly to explore what a specific instance of communal encounter might look like: the Church's encounter with secular society.

Given the Barthian construction of encounter, would it even be possible to speak of a communal encounter like that of the Church and society? That is, could the Church and society truly encounter one another in Barth's sense $?^{58}$ I maintain that such an encounter is conceivable, but only with certain qualifications, which are best outlined in reference to Barth's four elements of encounter: First, the Church and society could meet eye to eye only in the sense that both entities are embodied by humans, so they would encounter each other in humans and as humans. In personal encounter, humans meet eye to eye because they have an intrinsically equal dignity, so one cannot stand above the other. However, this would be less clear in terms of the Church vis-à-vis society, because while each is made up of humans with equal dignity, the Church certainly receives a priority in Barth — of claim on one's conscience, of witness to the gospel, of authority in teaching truth — that society does not. There would be no possibility of putting the

\footnotetext{
${ }^{57}$ Barth on inter-religious dialogue would be a worthy topic to explore, but one that runs beyond the limits of this discussion. Suffice it to say here that whatever he would say about other religions, he would certainly maintain that love of neighbor is in no way nullified simply by a difference of religion.

${ }^{58}$ One might wish to argue that these two entities are not even distinct enough from one another to constitute any type of encounter, whatever Barth might mean by the word. However, Barth is insistent that the Church, marked by Baptism, is a communal entity set apart from society, and thus (this discussion argues) is one capable of encountering others. (Cf. Karl Barth, The Teaching of the Church Regarding Baptism, trans. Ernest A. Payne (Eugene, OR: Whipf and Stock, 1948), esp. 25-33.)
} 
Church qua Church and society qua society on an equal footing; the Church and society in Barth's thought are not equals. Instead, the relationship between the Church and society would only be eye to eye to the extent that humans who constitute Church and society meet themselves and each other eye to eye.

Second, the communication exchange between Church and society would not necessarily be one of mutual enrichment. Rather, the Church, to a certain extent, stands apart from society as a prophetic witness to the life and work of Jesus Christ. In Barth's thought, what the Church receives from society is simply a context in which to witness, and a set of historical circumstances it must understand and challenge. Barth's model of Church/society interaction emphasizes proclamation of the gospel over mutual enrichment. As Rashkover points out, Barth's Christology allows the Church “....to positively proclaim the promise of the Kingdom of God,” and negatively his theology “....mandates [the Church's] prophetic separation from the state." 59

Third, if there is any mutual assistance possible between the Church and society, it would follow closely the characteristics of the communication exchange between the two, with one significant difference. While the role of the society would remain that of providing the Church a (hopefully friendly) context in which to proclaim the Good News, the role of the Church would grow beyond that of prophetic witness into intimating such a witness in works of charity. Recall that love of neighbor is the concrete form that true human encounter takes, so the Church's role in the encounter with society is to love the members of society, especially the poor. Failing to do so would invalidate the encounter, at least on the ecclesial side, and so would prevent the Church from really living as the Church.

\footnotetext{
${ }^{59}$ Rashkover, 180.
} 
Fourth and finally, the spirit of gladness would only be necessary on the part of the Church. Sin runs rampant in both the Church and society, but it is only the Church that is fully aware of the character of sin, and is called to exhibit a different kind of encounter, i.e., that characterized by gladness. Put plainly, prophetic witness and works of charity are not always met with open arms, and Barth would not be naïve in such regard. In fact, "gladness," when applied to the Church in relation to society, would likely look more like zeal and patience in suffering. ${ }^{60}$ Barth, in living through both world wars, was intimately familiar with the fact that Christians cannot always minister with what would present itself as gladness. Rather, the Church relies on a holy zeal to continue in its prophetic witness and ministry. Because true encounter is only possible by appropriating to some extent the revelation of Jesus Christ and the command of the Father, it is God's power that gives the Church's action (and the action of any created entity) weight. ${ }^{61}$ In Joseph L. Mangina's words, “....divine agency sets free genuine and effective human agency." ${ }^{\prime 2}$ In this light, the encounter of the Church and society, if it were to be characterized by gladness, would also draw zeal and endurance from the agency of God. In other words, God would animate this encounter as the common good—-for Barth, there would be no other way to conceive of it.

\section{Conclusion}

This discussion, after laying out Karl Barth's theological anthropology, has argued that Barth's concept of encounter provides a necessary basis for speaking about the common good from a Barthian perspective. While Barth's early formulations of theological ethics, especially as

\footnotetext{
${ }^{60}$ Joseph L. Mangina, Karl Barth on the Christian Life: The Practical Knowledge of God, Issues in Systematic Theology vol. 8 (New York: Peter Lang, 2001), 184-185.

${ }^{61}$ Karl Barth, Church Dogmatics III/3, $2^{\text {nd }}$ ed., trans. G.W. Bromiley, eds. G.W. Bromiley and T.F. Torrance (Peabody, MA: Hendrickson, 2010), 41-43.

${ }^{62}$ Mangina, 175.
} 
exhibited in The Epistle to the Romans, lent themselves to a rejection of ethical norms and guidelines (making them all but unhelpful for concrete Christian life), the development of Barth's theology as seen in the Church Dogmatics, provides a more complete picture of his thought. While continuing to refrain from naming explicit ethical norms, the Barth of the Dogmatics is able to build an ethics of love of neighbor on the foundation of his theological anthropology: that of true human encounter. To distill a vision of the common good requires some extrapolation from Barth's work, but it would take the shape of both personal and communal lives of encounter, characterized by Barth's four elements of encounter: seeing eye to eye, giving and receiving communication, exchanging mutual assistance, and doing all these in a spirit of gladness. In more concrete terms, a Barthian vision of the common good could take the form of the Church encountering society - the Church would live as a prophetic witness in society to the Good News of Christ, exhibiting love of its neighbors in gladness, zeal, and endurance. 